\title{
PENGGUNAAN MODEL RASCH UNTUK MENGANALISIS MISKONSEPSI BAGI TOPIK NOMBOR INTEGER
}

\section{(MISCONCEPTION ANALYSIS FOR INTEGER NUMBERS BY USING RASCH MODEL )}

\author{
Khong Wei Seng ${ }^{*}$ and Lim Hooi Lian² \\ ${ }^{1}$ Sekolah Menengah Jenis Kebangsaan Chung Hwa Confucian, 2, Persiaran Tembaga, \\ 11600 Pulau Pinang, Malaysia \\ ${ }^{2}$ School of Educational Studies, Universiti Sains Malaysia, 11800 USM Pulau Pinang, \\ Malaysia \\ *Corresponding author: seanson.kws85@yahoo.com
}

Published date: 24 December 2019

To cite this article: Khong Wei Seng, \& Lim Hooi Lian. (2019). Penggunaan model RASCH untuk menganalisis miskonsepsi bagi topik nombor integer. Asia Pacific Journal of Educators and Education, 34, 105-128. https://doi.org/10.21315/apjee2019.34.6

To link to this article: https://doi.org/10.21315/apjee2019.34.6

\begin{abstract}
Diagnostic Test for Operations Subtraction of Negative Integer Number (UDOPNIN) is constructed to identify misconceptions among form one students on subtraction operations involving negative integer numbers. Distractor analysis in Option Probability Curves (OPC) through RASCH model in this study was to identify types of misconceptions among form one students based on students' ability. The survey research method is used in this study to determine the achievement of the objectives of the study. A sample of 572 Form one students from 11 secondary schools in Penang state involved in this study, consisted of 298 boys and 274 girls. The analysis validity and reliability of UDOPNIN instrument by RASCH model showed standardised residual variance (PCA) is $70.4 \%$, the PTMEA CORR is between 0.12 to 0.68 provide the item can contribute to identify misconceptions of the respondents, 38 items (95\%) is fulfil the requirement in MNSQ infit and 35 items $(87.5 \%)$ is fulfil the requirement in MNSQ outfit, the result of $t$-test in Differential Item Functioning (DIF) for 40 items is between -2.0 to +2.0 , and the value of Content Validity Index (CVI) for UDOPNIN instrument is 0.80 . The OPC of 40 items in UDOPNIN instrument showed among the students' misconceptions on subtraction operations of negative integer numbers, majority of students who had problems of symbol misconceptions was because of pseudo-conception accommodation. The result of Winsteps version 3.57.2 showed that the item reliability index is 0.99 and the respondent reliability
\end{abstract}


index is 0.90 , which showed that the UDOPNIN instrument and the result of study are reliable and valid.

Keywords: Diagnostic test, misconception, RASCH model, Option Probability Curves (OPC), distractor analysis

\begin{abstract}
Abstrak: Ujian Diagnostik Operasi Penolakan Nombor Integer Negatif (UDOPNIN) dibina dalam kajian ini untuk mengenal pasti miskonsepsi murid tingkatan satu dalam topik operasi penolakan yang melibatkan nombor integer negatif. Analisis pengganggu (distractor analysis) dalam keluk Option Probability Curves (OPC) melalui model RASCH telah dijalankan dalam kajian ini untuk mengenal pasti jenis miskonsepsi yang dilakukan oleh murid tingkatan satu. Kaedah tinjauan digunakan dalam kajian ini untuk menentukan pencapaian objektif kajian. Seramai 572 orang murid tingkatan satu dari 11 buah sekolah menengah di seluruh negeri Pulau Pinang terlibat dalam kajian ini, antaranya 298 orang adalah murid lelaki dan 274 orang adalah murid perempuan. Analisis model Rasch dalam penentuan kesahan dan kebolehpercayaan instrumen UDOPNIN menunjukkan varians reja terpiawai (PCA) sebanyak 70.4\%, nilai PTMEA CORR di antara 0.12 hingga 0.68 dapat menyumbang kepada pengukuran miskonsepsi responden, sebanyak 38 item memenuhi keperluan MNSQ infit dan sebanyak 35 item memenuhi keperluan MNSQ outfit, nilai ujian- $t$ dalam Differential Item Functioning (DIF) bagi 40 item dalam lingkungan antara -2.0 hingga +2.0 , dan nilai Content Validity Index (CVI) dalam kesahan kandungan UDOPNIN bernilai 0.80. Keluk OPC 40 item dalam instrumen UDOPNIN memaparkan, dalam kalangan murid yang menghadapi miskonsepsi dalam operasi penolakan nombor integer negatif, majoriti bermasalah pseudo-konsepsi akomodasi yang menyebabkan miskonsepsi simbol. Hasil analisis perisian Winsteps versi 3.57.2 menunjukkan indeks kebolehpercayaan item bernilai 0.99 dan indeks kebolehpercayaan responden bernilai 0.90, hal ini membuktikan bahawa instrumen UDOPNIN dan dapatan kajian adalah boleh dipercayai dan sah.
\end{abstract}

Kata Kunci: Ujian diagnostik, miskonsepsi, model RASCH, OPC, analisis pengganggu

\title{
PENGENALAN
}

Matematik merupakan bidang yang melibatkan perkembangan pemikiran logik dan sistematik dalam menyelesaikan masalah, membuat keputusan dan penyiasatan aksiomatik yang menerangkan struktur abstrak dengan menggunakan logik dan simbol matematik (Bahagian Pembangunan Kurikulum, 2010). Manakala nombor integer pula merupakan salah satu topik yang melibatkan pembelajaran pengetahuan dan kemahiran berkaitan nombor. Kajian ini dijalankan berdasarkan sub-topik nombor integer untuk mengenal pasti miskonsepsi yang sering dilakukan dalam kalangan murid, terutamanya dalam bidang operasi penolakan nombor integer. 
Menurut Suparno (2005), miskonsepsi adalah suatu keadaan di mana konsep yang difahami tidak sama dengan konsep yang diperakui oleh ahli akademik.

Dalam kajian ini, miskonsepsi membawa maksud kesilapan atau kesalahfahaman oleh murid terhadap topik nombor-nombor integer khasnya bagi nombor integer negatif.

Berdasarkan laporan yang dikeluarkan oleh Lembaga Peperiksaan Malaysia (1993, 2002, 2003a, 2003b, 2007, 2010, 2012, 2014), ramai calon Penilaian Menengah Rendah (PMR) dan Sijil Pelajaran Malaysia (SPM) menghadapi masalah miskonsepsi dalam konsep asas operasi tambah, tolak, bahagi dan darab dalam nombor integer positif atau negatif. Buktinya, calon lemah dalam menjawab soalan melibatkan nombor integer negatif dan memberikan jawapan mereka seperti $[-6 \mathrm{w}-(\mathrm{w})=7 \mathrm{w}],[-15+(-4)=19],[-15-4=-11]$ dan $[-15+$ $4=11$ ] (Lembaga Peperiksaan Malaysia, 2003a). Berdasarkan sukatan pelajaran, topik nombor integer telahpun dipelajari oleh murid semasa di tingkatan satu dalam topik ke-6, Integer (Kurikulum Bersepadu Sekolah Menengah, KBSM) atau topik pertama, Nombor Nisbah (Kurikulum Standard Sekolah Menengah, KSSM). Ini bermaksud kebanyakan murid tidak dapat menguasai konsep asas nombor integer dan mengalami miskonsepsi semasa tingkatan satu. Keadaan ini akan membawa impak yang besar semasa murid melanjutkan tingkatan dua, tiga, empat dan lima seterusnya menjejaskan keputusan matematik mereka. Di samping itu, miskonsepsi ini turut menjejaskan kefahaman mereka dalam topik yang lain seperti dalam pecahan, tranformasi dan algebra. Masalah miskonsepsi ini memang membimbangkan kerana operasi aritmetik nombor negatif merupakan konsep yang paling asas dalam matematik. Oleh itu, penguasaan konsep asas nombor integer perlu dititik beratkan dari awal untuk memastikan bahawa masalah miskonsepsi tidak berlaku pada tahap pembelajaran yang seterusnya.

Kajian-kajian lepas yang dijalankan di Malaysia mahupun di luar negara hanya memberi fokus kepada tahap kefahaman murid terhadap nombor integer khasnya integer negatif (Bofferding, 2010, 2014; Ahmad Badli Sah, 1999; Marlina \& Nurhidayah, 2011; Wong, 2012; Bolyard \& Moyer-Packenham, 2012) dan mengkaji tentang cara pemikiran murid dalam miskonsepi nombor negatif (Periasamy \& Halimah Badioze Zaman, 2011, 2012; Periasamy, 2014) serta jenisjenis miskonsepsi nombor integer murid (Mohammad Sopian, 2011; Sadler, 2012; Titikusumawati, 2013; Normunirah, 2006). Kaedah kualitatif yang digunakan oleh kajian-kajian lepas ini seperti temu duga dan analisis miskonsepsi murid dengan soalan pendek mempunyai beberapa limitasi dari aspek metodologi. Kaedah klasik yang digunakan dalam kajian terdahulu, dengan menganalisis data seperti min skor dan sisihan piawai, darjah kebolehpercayaan instrumen dengan kaedah 
formula Kuder-Richardson (KR20) mempunyai dua kelemahan, iaitu masalah bergantung-kumpulan (respondent-depend) dan masalah bergantung-item (itemdepend) (Bhasah, 2007).

Justeru, model Rasch yang merupakan salah satu model dalam Teori Respons Item (Item Response Theory, IRT) dikatakan lebih sesuai digunakan untuk menganalisis miskonsepsi nombor integer murid melalui soalan-soalan aneka pilihan, kerana model ini mempunyai dua ciri keistimewaan: pertama, model Rasch melibatkan parameter yang paling sedikit, oleh itu ia lebih mudah diaplikasikan; kedua, model Rasch mempunyai objektif yang spesifik iaitu membenarkan pemisahan lengkap item dan keupayaan anggaran (Hambleton \& Rogers, 1989). Penggunaan keluk Option Probability Curves (OPC) dalam model Rasch untuk mengenal pasti jenis miskonsepsi yang dilakukan oleh murid dalam kajian ini adalah berdasarkan aras kebolehan murid. Cara ini lebih mudah dan lebih sistematik berbanding dengan kaedah yang digunakan oleh kajian lepas. Hal ini bermakna, keluk OPC mempunyai kelebihan dari aspek mengenal pasti miskonsepsi murid, jenis miskonsepsi yang dihadapi oleh murid dari aras kebolehan tinggi dan aras kebolehan rendah. Analisis keluk OPC dalam model Rasch lebih tinggi darjah kebolehpercayaan berbanding dengan analisis miskonsepsi kajian lepas dengan kaedah peratusan (Herrmann \& DeBoer, 2011, 2016; Lily \& Su-Jen, 2015), kerana miskonsepsi murid dalam keluk OPC dianalisis berdasarkan aras kebolehan murid, bukannya secara purata atau peratusan.

\section{TUJUAN KAJIAN}

Kajian ini bertujuan untuk mengenal pasti jenis miskonsepsi murid dalam topik operasi penolakan yang melibatkan nombor integer dalam kalangan murid tingkatan satu dengan menggunakan model Rasch melalui Ujian Diagnostik UDOPNIN. 


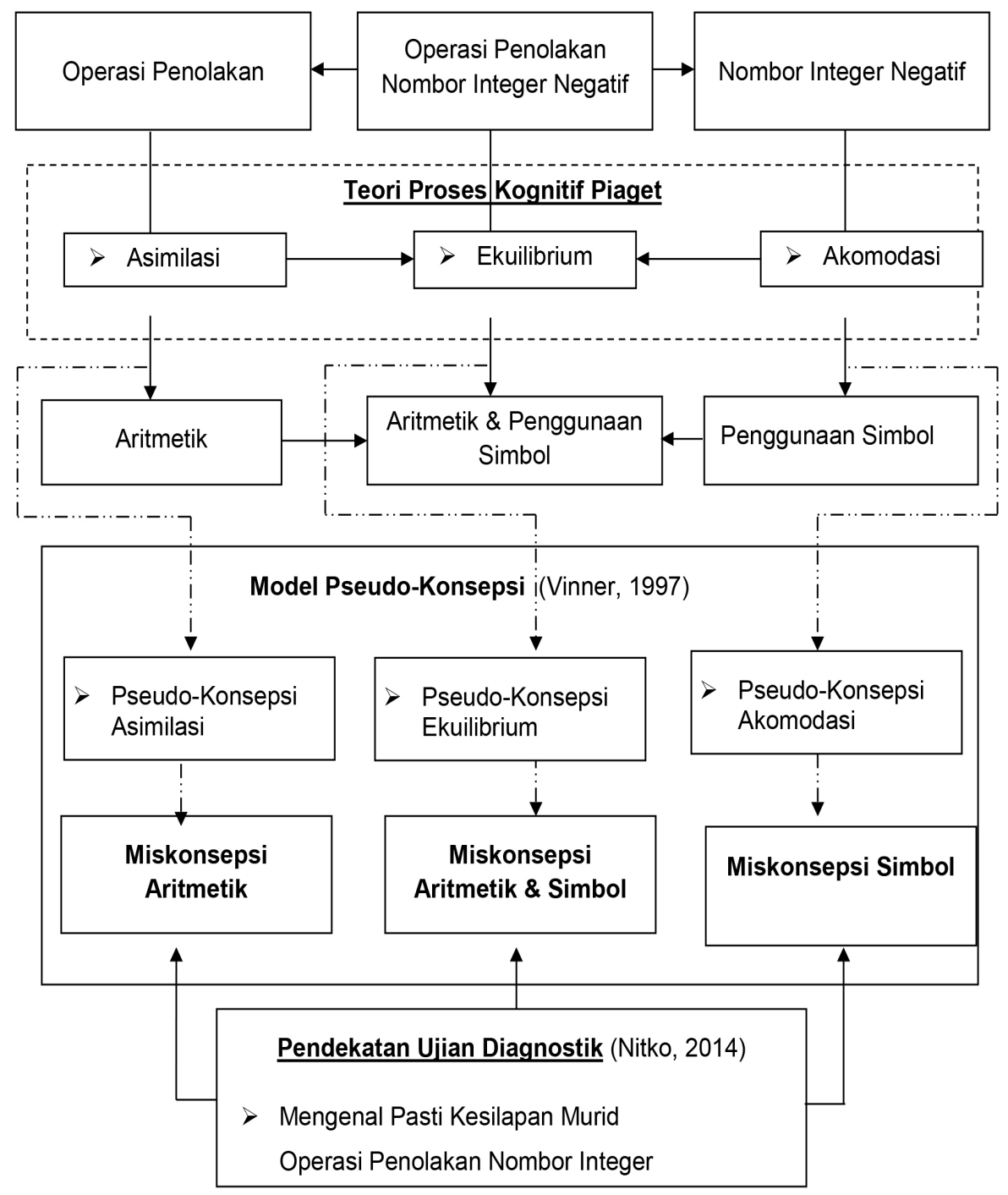

Petunjuk:

$-\cdots-\cdot-\cdots-$ Berlaku Miskonsepsi

Rajah 1. Kerangka Teori Kognitif Piaget dan Model Pseudo-Konsepsi 


\section{KERANGKA TEORI}

Teori kognitif Piaget dan model pseudo-konsepsi yang dikemukakan oleh Vinner (1997) telah diaplikasikan dalam kajian ini untuk mengenal pasti jenis miskonsepsi murid tingkatan satu dalam topik operasi penolakan nombor integer khususnya integer negatif. Menurut Piaget (dalam Kamarudin \& Siti Hajar, 2004), perkembangan kognitif merupakan suatu proses genetik, iaitu sesuatu proses yang melibatkan kaedah biologi dalam perkembangan sistem saraf. Semakin meningkat umur seseorang, semakin kompleks susunan sel sarafnya dan semakin meningkat keupayaannya (Kamarudin Husin \& Siti Hajar, 2004). Menurut beliau, dalam proses belajar apabila seseorang menghadapi rangsangan baru (perkara baru), terdapat dua proses yang digunakan oleh individu untuk cuba adaptasinya, iaitu asimilasi dan akomodasi (Subanji \& Toto Nusantara, 2016).

Asimilasi adalah suatu proses perubahan atau penggunaan rangsangan baru yang dihadapi untuk diletakkan di dalam struktur kognitif yang sedia ada (Subanji \& Toto Nusantara, 2016). Seseorang individu dikatakan melakukan proses adaptasi melalui asimilasi, jika individu tersebut menggabungkan informasi baru yang terima ke dalam pengetahuan mereka yang sedia ada. Dalam kajian ini, proses asimilasi dikatakan dilakukan oleh murid dengan menyelesaikan soalan operasi penolakan antara dua nombor integer yang melibatkan proses aritmetik. Akomodasi pula adalah suatu proses perubahan struktur kognitif seseorang untuk menyesuaikan dirinya terhadap rangsangan baru (Subanji \& Toto Nusantara, 2016). Oleh itu, akomodasi berlaku jika individu menyesuaikan diri dengan informasi baru, struktur kognitif yang sedia ada mengalami perubahan supaya sesuai dengan rangsangan yang diterima. Dalam kajian ini, proses akomodasi dikatakan berlaku semasa murid menyelesaikan soalan yang melibatkan nombor integer negatif yang menggunakan simbol negatif dalam operasi penolakan. Semasa murid cuba menyelesaikan soalan-soalan yang melibatkan operasi penolakan bagi dua nombor integer negatif, murid tersebut dikatakan sedang melakukan proses ekuilibrium (keseimbangan proses asimilasi dan akomodasi), kerana pada masa yang sama murid melibatkan proses aritmetik yang menggunakan simbol negatif (rujuk Rajah 1).

Pemikiran pseudo adalah satu proses pemikiran yang menghasilkan jawapan kepada sesuatu masalah atau pembinaan kepada konsep "yang tidak betul" (Subanji \& Toto Nusantara, 2016; Vinner, 1997). Dengan kata lain, pemikiran pseudo adalah satu proses pembinaan konsep murid yang tidak mewakili pemikiran sebenar yang disampaikan oleh pakar. Vinner (1997) mengemukakan model pseudokonsepsi: satu keadaan atau proses di mana murid gagal menguasai makna sebenar yang disampaikan dalam satu konsep (miskonsepsi). Menurut Subanji dan Toto 
Nusantara (2016), miskonsepsi yang dilakukan oleh murid dalam matematik perlu diberi perhatian oleh para pendidik, miskonsepsi yang serius boleh menjejaskan pemahaman murid terhadap konsep matematik seterusnya.

Dalam kajian ini, semasa seseorang murid menyelesaikan soalan matematik operasi penolakan nombor integer negatif, proses kognitif murid akan menjalankan kognitif ekuilibrium yang melibatkan keseimbangan kognitif asimilasi dan akomodasi. Kognitif asimilasi melibatkan operasi penolakan antara dua nombor (aritmetik) dan kognitif akomodasi melibatkan pemahaman konsep nombor integer negatif (penggunaan simbol) (rujuk Rajah 1). Murid dapat mencapai kognitif ekuilibrium sekiranya kedua-dua proses kognitif asimilasi dan akomodasi berjaya dilakukan. Akan tetapi, kegagalan dalam proses kognitif akan menyebabkan model pseudokonsepsi, iaitu gagal menguasai makna sebenar yang disampaikan dalam satu konsep. Kegagalan murid dalam kognitif asimilasi akan menyebabkan pseudokonsepsi asimilasi yang gagal dalam operasi penolakan antara dua nombor (miskonsepsi aritmetik). Kegagalan murid dalam kognitif akomodasi akan menyebabkan pseudo-konsepsi akomodasi yang gagal dalam pemahaman konsep nombor integer negatif (miskonsepsi simbol negatif). Kegagalan murid dalam kognitif ekuilibrium akan menyebabkan pseudo-konsepsi ekuilibrium yang gagal dalam menyelesaikan soalan matematik operasi penolakan nombor integer negatif (miskonsepsi aritmetik dan simbol negatif) (rujuk Rajah 1).

\section{KAEDAH KAJIAN}

Dalam kajian ini, data dan maklumat dikumpul secara kuantitatif dalam bentuk data berangka. Kaedah tinjauan (survey research) digunakan untuk menentukan pencapaian objektif kajian. Kaedah persampelan secara rawak (random sample) dengan cara persampelan berkelompok (cluster sampling), atau lebih dikenali sebagai persampelan rawak berkelompok (ramdom cluster sampling) digunakan dalam kajian ini untuk memilih sampel responden kajian ini. Seramai 572 orang murid tingkatan satu dari 11 buah sekolah menengah di seluruh negeri Pulau Pinang terlibat dalam kajian ini. Antaranya, 298 orang adalah murid lelaki dan 274 orang adalah murid perempuan.

Instrumen UDOPNIN telah dibina berdasarkan Dokumen Standard Kurikulum dan Pentaksiran Matematik Tingkatan 1 (DSKP) dalam sukatan pelajaran KSSM. Jadual Spesifikasi Item (JSI) dibina bagi rujukan pembinaan instrumen. Instrumen UDOPNIN ini mengandungi 40 soalan objektif atau dikenali sebagai soalan aneka pilihan berpandukan 4 kategori operasi dan 2 jenis penolakan yang mempunyai 4 pilihan jawapan. Selain daripada satu pilihan sebagai jawapan betul, tiga pilihan 
lagi berfungsi sebagai pengganggu untuk mengenal pasti jenis miskonsepsi murid. Pembinaan instrumen UDOPNIN ini adalah berdasarkan model pembinaan yang dikemukakan oleh Cohen, Swerdlik dan Sturman (2013) dan Nitko (2014), pendekatan ke-4: mengenal pasti kesilapan murid - bertujuan untuk mengenal pasti jenis-jenis ketidakfahaman, kesilapan, salah faham, atau miskonsepsi yang sering dilakukan oleh murid.

Analisis andaian-andaian model Rasch dalam penentuan kesahan dan kebolehpercayaan instrumen UDOPNIN menunjukkan varians reja terpiawai (PCA) sebanyak $70.4 \%$ dan nilai ambang bagi varians mentah tidak jelas faktor 1 , 2, 3, 4 dan 5 bernilai 3.9, 2.9, 2.6, 2.2 dan $1.5(<5$ : Linacre, 2003), nilai PTMEA CORR di antara 0.12 hingga 0.68 ( $\geq 0.3$ : Linacre, 2003) dapat menyumbang kepada pengukuran miskonsepsi responden kerana masih bernilai positif (Bond \& Fox, 2015), sebanyak 38 item (95\%) memenuhi keperluan MNSQ infit (0.6-1.4: Linacre, 2003) dan sebanyak 35 item (87.5\%) memenuhi keperluan MNSQ outfit (0.6-1.4: Linacre, 2003), nilai ujian- $t$ dalam Differential Item Functioning (DIF) bagi 40 item dalam lingkungan antara -2.0 hingga +2.0 (Alquraan, Alshraideh, \& Bsharah, 2010), dan nilai Content Validity Index (CVI) dalam kesahan kandungan UDOPNIN bernilai 0.80 (>0.78: Lynn, 1986).

Semasa proses pengumpulan data, murid-murid telah diminta duduk dalam bentuk seperti kedudukan ujian dan diberi masa 30 minit untuk menjawab. Data kajian ini disemak secara manual sebelum perisian Winsteps versi 3.57.2 digunakan untuk mengenal pasti jenis miskonsepsi yang dilakukan oleh murid dalam operasi penolakan nombor integer negatif. Analisis pengganggu (distractor analysis) bagi setiap item telah dijalankan menggunakan model Rasch. Indeks kebolehpercayaan item bernilai 0.99 dan indeks kebolehpercayaan responden bernilai 0.90 membuktikan kajian ini boleh dipercayai dan sah (Fleiss, 1981).

\section{DAPATAN KAJIAN}

Analisis pengganggu akan dijalankan untuk mengenal pasti jenis miskonsepsi yang dilakukan oleh murid tingkatan satu berdasarkan model pseudo-konsepsi melalui penyemakan keluk OPC. Analisis pengganggu dijalankan berdasarkan 4 kategori jenis operasi penolakan iaitu: (i) operasi penolakan integer positif dengan integer positif, (ii) operasi penolakan integer negatif dengan integer positif, (iii) operasi penolakan integer positif dengan integer negatif, dan (iv) operasi penolakan integer negatif dengan integer negatif. 
Berdasarkan keluk OPC, selain pilihan jawapan yang betul (keluk OPC berbentuk seperti keluk ICC - Item Characteristic Curve), tiga pilihan pengganggu yang lain dikatakan mempunyai kebarangkalian yang rendah pada setiap aras kebolehan murid (keluk OPC berbentuk mengufuk) (Herrmann \& DeBoer, 2011; 2016; Wind \& Gale, 2015; Lily \& Su-Jen, 2015). Sekiranya keluk OPC bagi mana-mana pengganggu tidak berbentuk mengufuk pada aras kebarangkalian yang rendah, murid dikatakan menghadapi miskonsepsi bagi item tersebut, dan jenis miskonsepsi yang dihadapi adalah berdasarkan pilihan pengganggu murid. Dengan kata lain, jika kebarangkalian bagi mana-mana keluk OPC pengganggu mempunyai nilai yang tinggi, bermakna murid menghadapi miskonsepsi bagi pilihan pengganggu tersebut (Herrmann \& DeBoer, 2011; 2016; Wind \& Gale, 2015; Lily \& Su-Jen, 2015).

\section{Operasi Penolakan Integer Positif dengan Integer Positif}

Kategori operasi penolakan ini terbahagi kepada kumpulan nombor mutlak besar menolak nombor mutlak kecil $(\mathrm{a}-\mathrm{b}=,|\mathrm{a}|>|\mathrm{b}|)$, dan nombor mutlak kecil menolak nombor mutlak besar $(\mathrm{a}-\mathrm{b}=,|\mathrm{a}|<|\mathrm{b}|)$. Rajah 2 hingga 6 merupakan OPC bagi item-item bagi kumpulan $(\mathrm{a}-\mathrm{b}=,|\mathrm{a}|>|\mathrm{b}|)$. Kelima-lima item ini (item $6,14,22,32$, dan 38) mempunyai pilihan jawapan A untuk mengesan miskonsepsi aritmetik murid yang menghadapi pseudo-konsepsi asimilasi, pilihan jawapan $\mathrm{C}$ untuk mengesan miskonsepsi simbol murid yang menghadapi pseudo-konsepsi akomodasi, dan pilihan jawapan D yang mengesan miskonsepsi aritmetik dan simbol murid yang menghadapi pseudo-konsepsi ekuilibrium, manakala jawapan B merupakan jawapan betul; mewakili murid yang dapat menguasai sub-topik ini.

Berdasarkan Rajah 2 hingga 6 (item 6, 14, 22, 32, dan 38), dapat dirumuskan bahawa dalam operasi penolakan integer positif dengan integer positif kategori $(|\mathrm{a}|$ $>|b|)$, murid yang menghadapi miskonsepsi kebanyakannya adalah miskonsepsi aritmetik (pilihan jawapan A) yang disebabkan masalah pseudo-konsepsi asimilasi.

Rajah 2 hingga 6 menunjukkan bahawa semua tahap kebolehan murid dapat menguasai sub-topik ini, kerana setiap aras kebolehan murid (-2.0 logit hingga 1.0 logit) mempunyai kebarangkalian yang tinggi (lebih kurang 0.8 logit) untuk menjawab betul bagi item-item tersebut (pilihan jawapan B), kecuali pada aras kebolehan murid pada -2.0 logit hingga -1.5 logit mencatat kebarangkalian yang lebih rendah (0.6 logit). Sukar untuk membezakan kebolehan sebenar murid dalam penguasaan topik operasi penolakan nombor integer negatif berdasarkan item-item dalam kategori ini. Dari aspek miskonsepsi pula, terdapat segelintir murid bagi aras kebolehan yang rendah $(-2.0$ logit hingga -1.5 logit $)$ menghadapi miskonsepsi aritmetik akibat daripada pseudo-konsepsi asimilasi (pilihan jawapan A), khasnya 
bagi item 6, 32, dan 38. Manakala item 14 dan 22 pula menunjukkan segelintir murid bagi aras kebolehan rendah $(-2.0$ logit hingga -1.5 logit $)$ menghadapi pseudo-konsepsi akomodasi yang membawa miskonsepsi simbol (pilihan jawapan C). Item ke-14 merupakan item yang istimewa, kerana pada aras kebolehan murid yang tinggi $(0.5$ logit hingga 1.0 logit) terdapat murid mengalami miskonsepsi aritmetik.

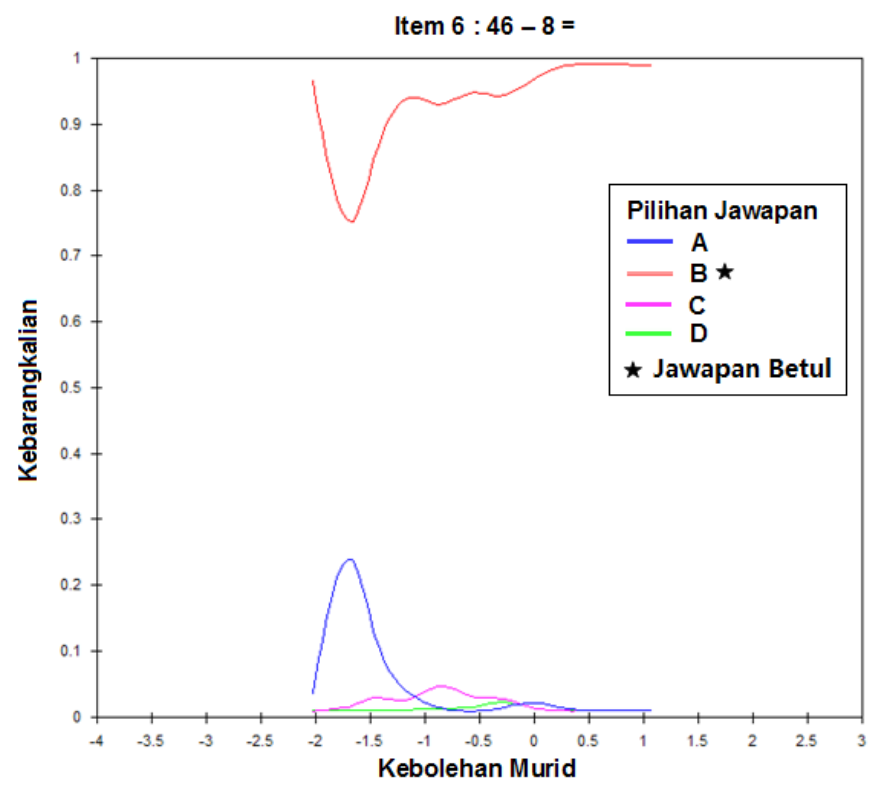

Rajah 2. Keluk Kebarangkalian Pilihan Item 6 


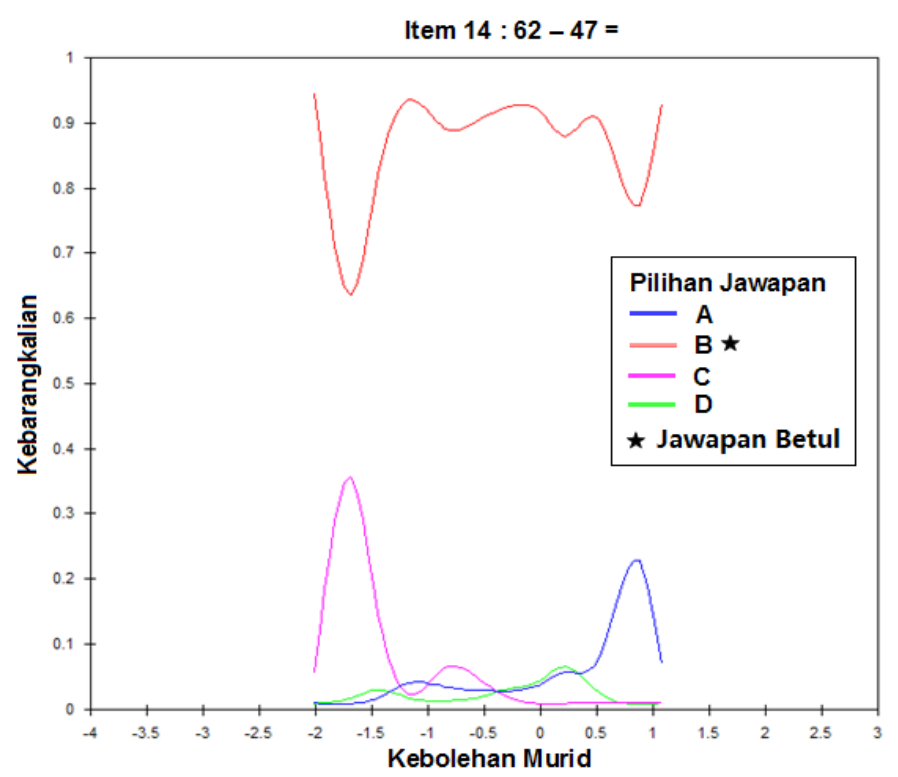

Rajah 3. Keluk Kebarangkalian Pilihan Item 14

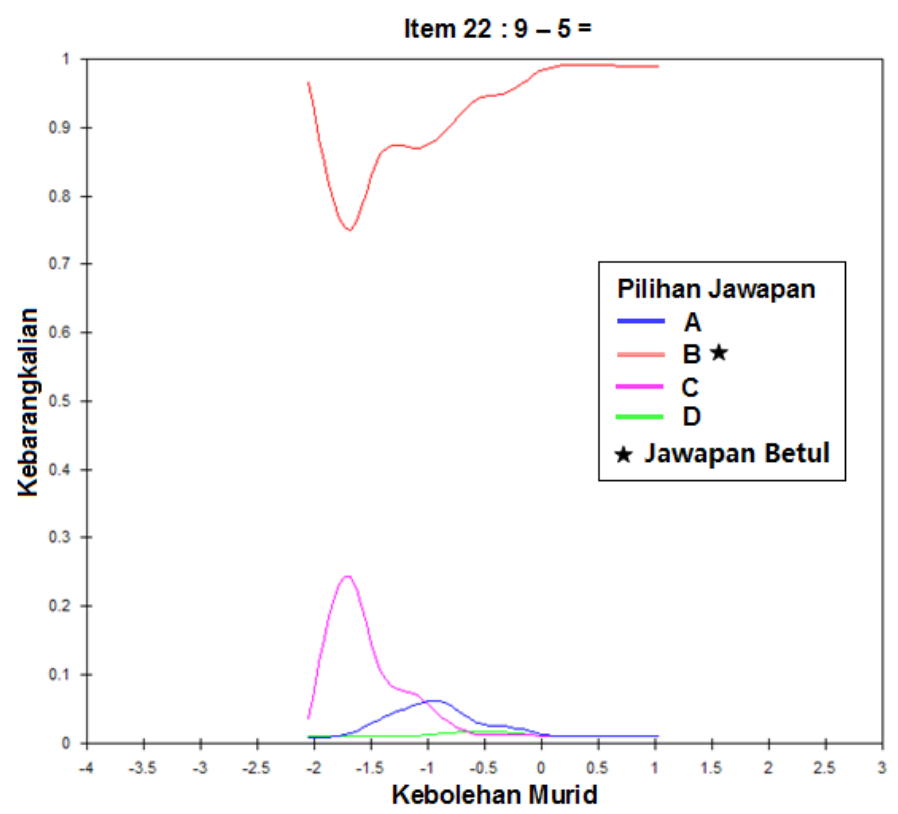

Rajah 4. Keluk Kebarangkalian Pilihan Item 22 


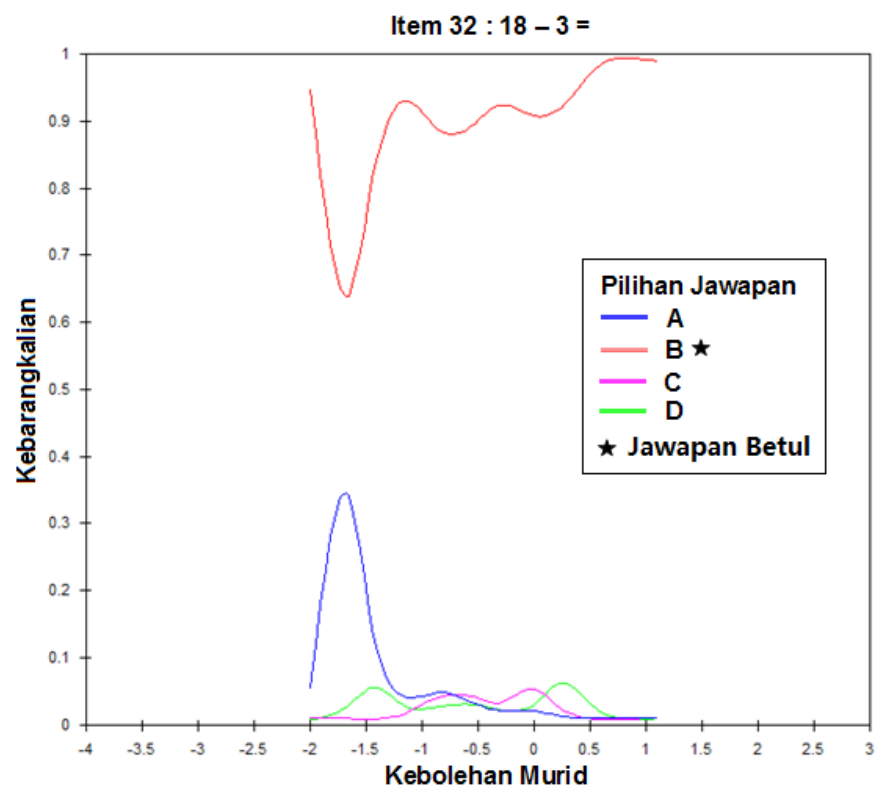

Rajah 5. Keluk Kebarangkalian Pilihan Item 32

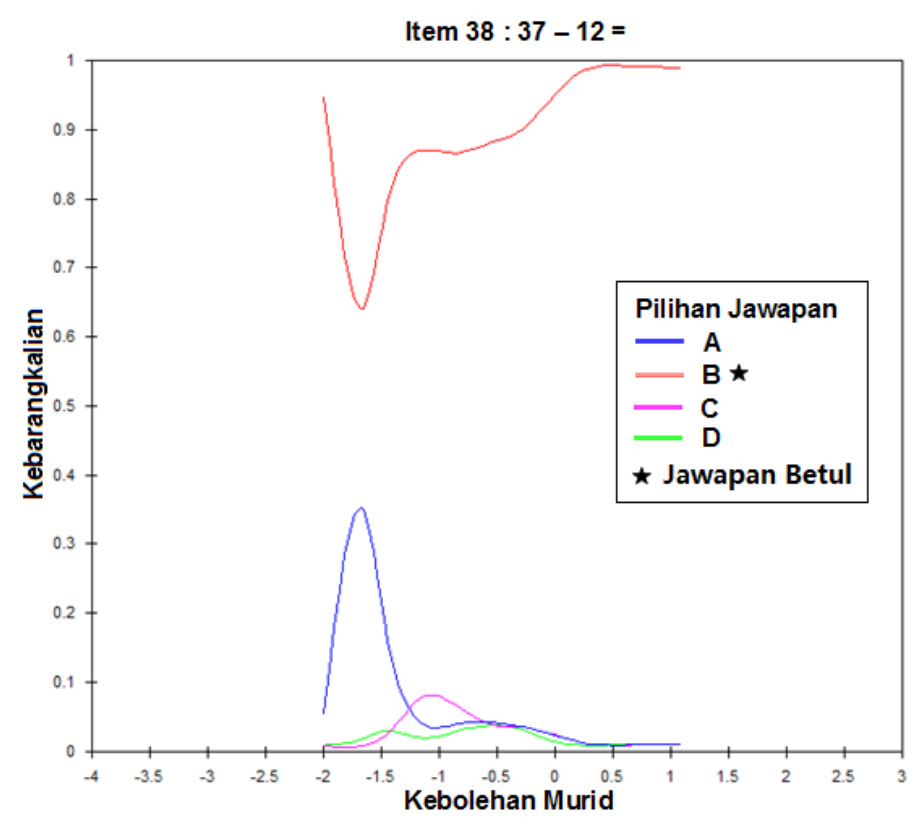

Rajah 6. Keluk Kebarangkalian Pilihan Item 38 


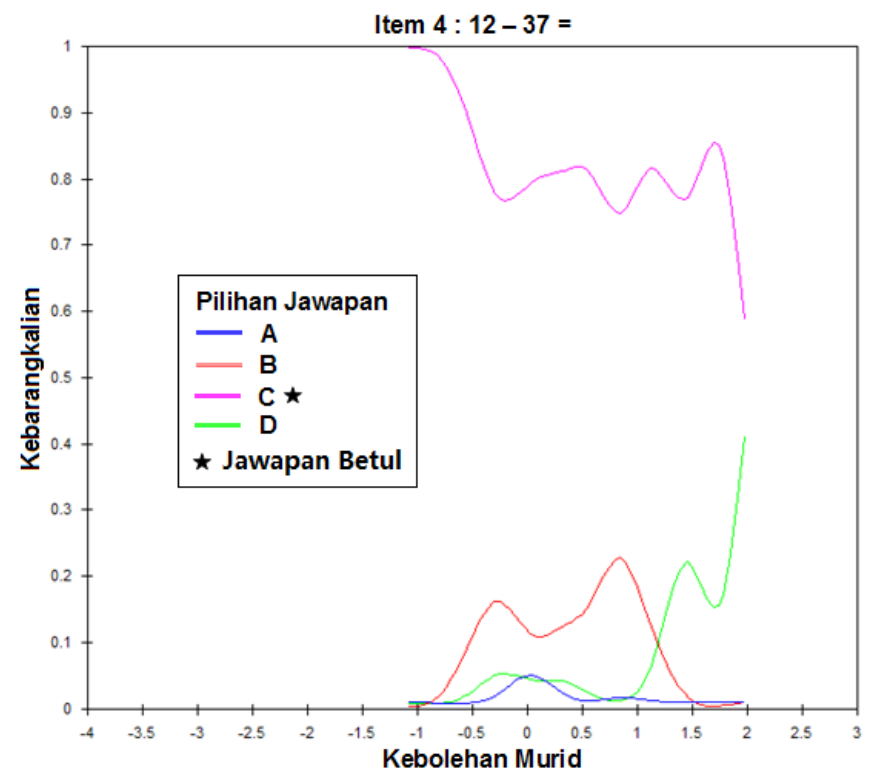

Rajah 7. Keluk Kebarangkalian Pilihan Item 4

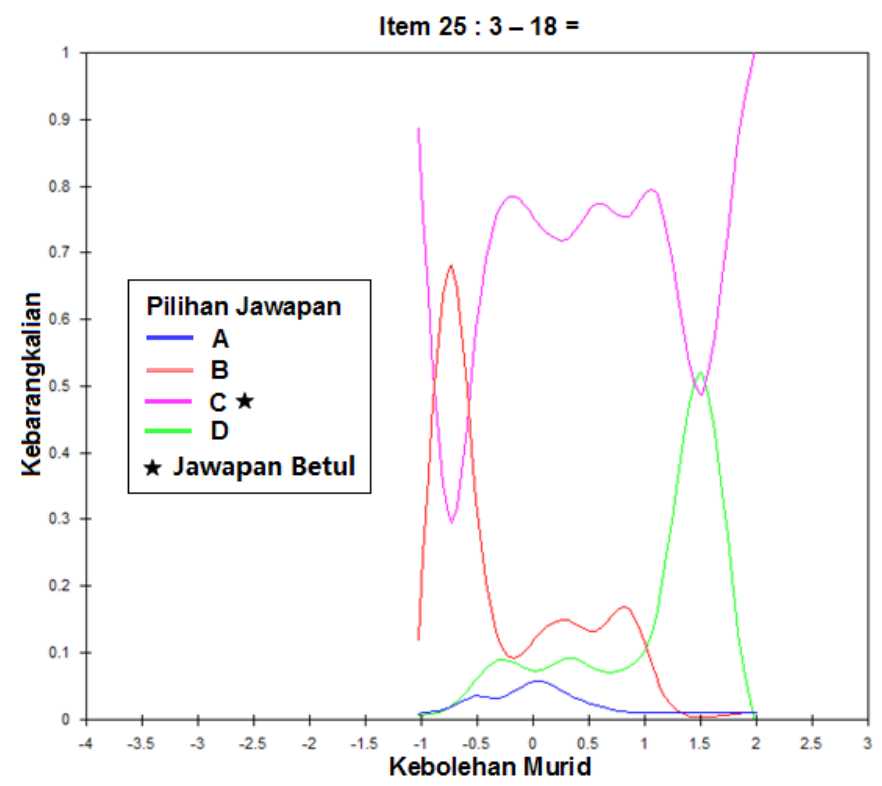

Rajah 8. Keluk Kebarangkalian Pilihan Item 25 


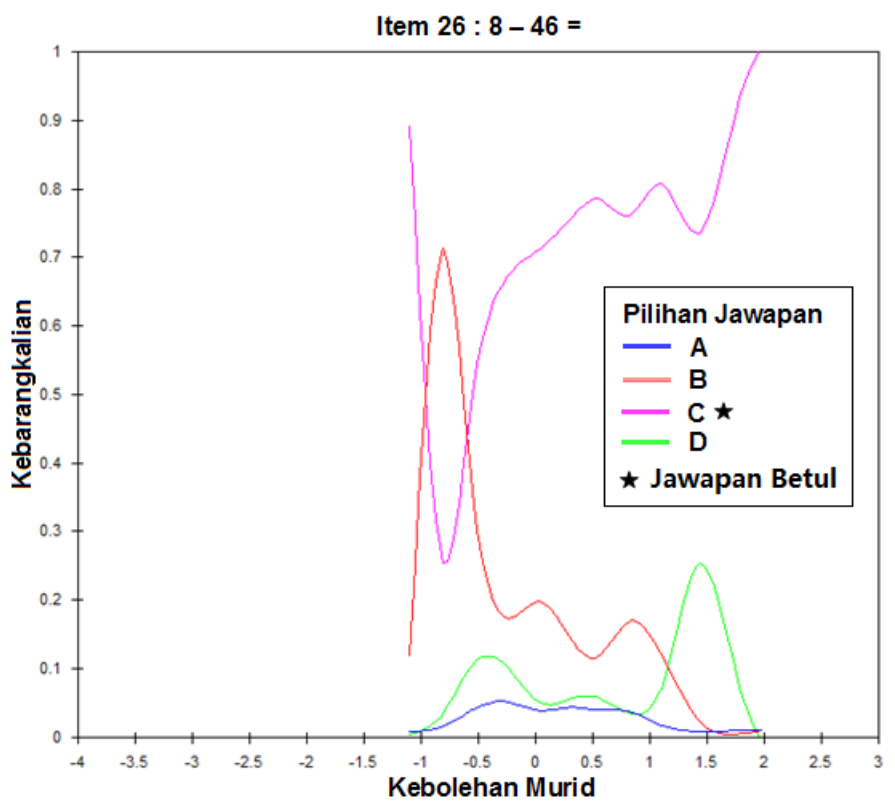

Rajah 9. Keluk Kebarangkalian Pilihan Item 26

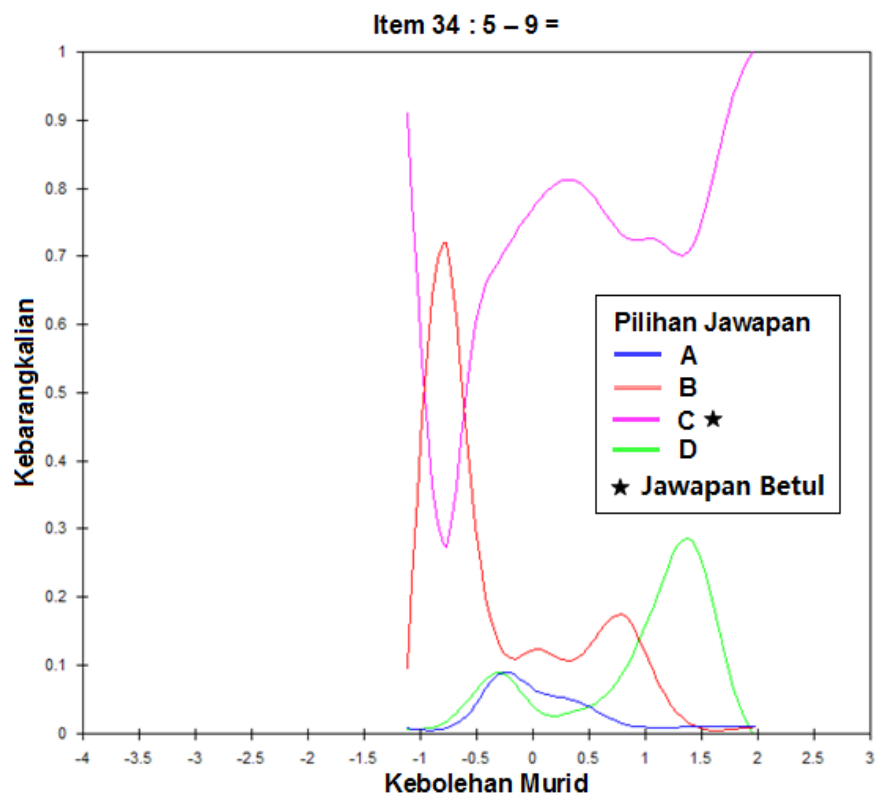

Rajah 10. Keluk Kebarangkalian Pilihan Item 34 


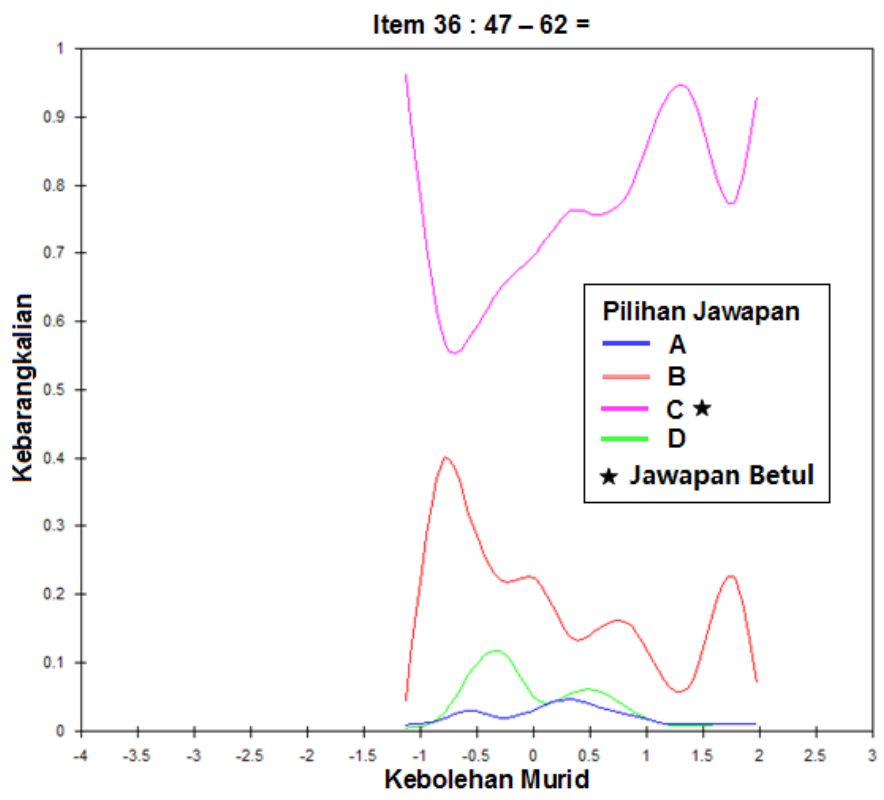

Rajah 11. Keluk Kebarangkalian Pilihan Item 36

Item 4, 25, 26, 34, dan 36 pula merupakan item-item operasi penolakan integer positif dengan integer positif kategori nombor mutlak kecil menolak nombor mutlak besar $(a-b=,|a|<|b|)$. Keluk OPC bagi item-item kategori ini telah ditunjukkan dalam Rajah 7 hingga Rajah 11. Pilihan jawapan A bagi kelima-lima item ini dibina untuk mengesan miskonsepsi aritmetik dan simbol murid yang menghadapi pseudo-konsepsi ekuilibrium, pilihan jawapan B untuk mengesan miskonsepsi simbol murid yang menghadapi pseudo-konsepsi akomodasi, pilihan jawapan D yang mengesan miskonsepsi aritmetik murid yang menghadapi pseudokonsepsi asimilasi, dan jawapan $\mathrm{C}$ merupakan jawapan betul yang mewakili murid dapat menguasai sub-topik ini.

Berdasarkan item 4, 25, 26, 34, dan 36 (Rajah 7 hingga 11), dapat dirumuskan bahawa dalam operasi penolakan integer positif dengan integer positif kategori $(|a|<|b|)$, murid yang menghadapi miskonsepsi kebanyakannya adalah miskonsepsi simbol (pilihan jawapan B) yang disebabkan masalah pseudo-konsepsi akomodasi.

Berdasarkan keluk OPC yang dipaparkan oleh item 4 dan 36, kedua-dua item ini menunjukkan semua aras kebolehan murid dapat menguasai item tersebut, kerana semua aras kebolehan murid dari -1.5 logit hingga 2.0 logit memilih pilihan jawapan betul (pilihan C). Manakala item 25, 26 dan 34 pula menunjukkan aras 
kebolehan murid pada -1.5 logit hingga -1.0 logit dan -0.5 logit hingga 2.0 logit kebanyakan telah memilih jawapan yang betul (pilihan $\mathrm{C}$ ), tetapi pada aras kebolehan murid -1.0 logit hingga -0.5 logit telah memilih pilihan B sebagai jawapan mereka. Ketiga-tiga item 25, 26 dan 34 ini telah membuktikan murid pada aras kebolehan -1.0 logit hingga -0.5 logit mengalami pseudo-konsepsi akomodasi yang membawa miskonsepsi simbol. Item 4, 25, 26, dan 34 juga menunjukkan bahawa pada aras kebolehan murid sekitar 1.5 logit, lebih ramai murid telah memilih D sebagai jawapan mereka kerana menghadapi miskonsepsi aritmetik kesan daripada pseudo-konsepsi asimilasi. Merujuk kepada Rajah 7, item 4 menunjukkan, pada aras kebolehan murid -0.5 logit hingga 1.0 logit terdapat segelintir murid menghadapi miskonsepsi simbol, kerana pseusokonsepsi akomodasi telah menyebabkan murid pada aras ini memilih jawapan B. Miskonsepsi simbol yang dihadapi oleh segelintir murid pada aras kebolehan -1.2 logit hingga 2.0 logit untuk item 36 pada Rajah 11, telah membuktikan pseudokonsepsi akomodasi dihadapi oleh murid berkenaan sehingga menyebabkan murid tersebut memilih jawapan B.

Ringkasan daripada Jadual 1, dalam operasi penolakan integer positif dengan integer positif kategori $(|\mathrm{a}|>|\mathrm{b}|)$, murid yang menghadapi miskonsepsi kebanyakannya adalah miskonsepsi aritmetik berbanding miskonsepsi simbol. Sebaliknya, lebih banyak murid menghadapi miskonsepsi simbol berbanding miskonsepsi aritmetik dalam kategori $(|a|<|b|)$. Walau bagaimanapun, dalam golongan murid mengalami miskonsepsi, kebanyakan miskonsepsi yang dihadapi oleh murid tingkatan satu dalam operasi penolakan integer positif dengan integer positif adalah miskonsepsi aritmetik, kesan daripada pseudo-konsepsi asimilasi. Pseudo-konsepsi ekuilibrium yang membawa miskonsepsi aritmetik dan simbol kurang dihadapi oleh murid tingkatan satu dalam operasi penolakan integer positif dengan integer positif.

Sebagai rumusan, jenis-jenis miskonsepsi yang dihadapi oleh murid tingkatan satu dapat diteliti melalui Jadual 2. Oleh itu, dapat disimpulkan bahawa kebanyakan murid-murid menghadapi miskonsepsi simbol (pseudo-konsepsi akomodasi), diikuti dengan miskonsepsi aritmetik (pseudo-konsepsi asimilasi), dan akhirnya merupakan miskonsepsi aritmetik dan simbol (pseudo-konsepsi ekuilibrium). Pseudo-konsepsi akomodasi (miskonsepsi simbol) adalah masalah yang paling ramai murid tingkatan satu hadapi semasa menyelesaikan soalan operasi penolakan nombor integer negatif. 
Jadual 1. Analisis miskonsepsi item operasi penolakan integer positif dengan integer positif

\begin{tabular}{lcccc}
\hline & & \multicolumn{3}{c}{ Jenis miskonsepsi } \\
\cline { 3 - 5 } $\mathrm{a}-\mathrm{b}$ & Nombor item & $\begin{array}{c}\text { Aritmetik (pseudo- } \\
\text { konsepsi asimilasi) }\end{array}$ & $\begin{array}{c}\text { Simbol (pseudo- } \\
\text { konsepsi akomodasi) }\end{array}$ & $\begin{array}{c}\text { Arimbol (pseudo- } \\
\text { konsepsi } \\
\text { ekuilibrium) }\end{array}$ \\
\hline$|\mathrm{a}|>|\mathrm{b}|$ & 6 & $\bullet$ & $\bullet$ \\
& 14 & $\bullet$ & $\bullet$ & \\
& 22 & $\bullet$ & & \\
& 32 & $\bullet$ & $\bullet$ & \\
& 38 & $\bullet$ & $\bullet$ & \\
& 25 & $\bullet$ & $\bullet$ & $\bullet$ \\
\hline
\end{tabular}

\section{PERBINCANGAN}

Majoriti murid menghadapi miskonsepsi aritmetik yang disebabkan oleh masalah pseudo-konsepsi asimilasi semasa cuba menyelesaikan soalan operasi penolakan yang melibatkan integer positif dengan integer positif. Secara keseluruhannya, majoriti murid tingkatan satu yang mengalami miskonsepsi dalam kajian ini adalah mereka yang bermasalah pseudo-konsepsi akomodasi yang membawa kepada miskonsepsi simbol semasa menyelesaikan soalan dalam instrument UDOPNIN. Ekoran itu, dapat dikatakan kebanyakan murid gagal melakukan proses kognitif akomodasi semasa cuba menyelesaikan soalan dalam instrumen UDOPNIN. Kegagalan murid dalam kognitif akomodasi yang melibatkan murid menyesuaikan dirinya terhadap rangsangan baru (Subanji \& Toto Nusantara, 2016) dengan nombor integer negatif yang menggunakan simbol negatif telah berlaku dalam kalangan responden kajian ini. Kegagalan ini turut mencetus masalah pseudokonsepsi akomodasi murid justeru menyebabkan miskonsepsi simbol, iaitu kegagalan kognitif akomodasi dalam menguasai nombor integer negatif. Dengan kata lain, murid telah salah faham terhadap fungsi sebenar simbol negatif dalam nombor integer negatif dan membawa miskonsepsi simbol semasa menyelesaikan soalan dalam instrumen UDOPNIN. 
Berdasarkan kajian-kajian lepas yang dijalankan oleh Laura Bofferding (2010; 2014), Ahmad Badli Sah (1999), Marlina dan Nurhidayah (2011), Sadler (2012), Titikusumawati (2013), Nyiayu, Didi dan Turmudi (2017), Normunirah (2006), Periasamy dan Halimah Badioze Zaman (2011; 2012), dan Periasamy (2014) mengenai miskonsepsi nombor integer, mereka lebih berfokus kepada mengenal pasti jenis-jenis miskonsepsi yang berlaku dalam kalangan murid, tiada kesimpulan dilakukan oleh pengkaji terhadap jenis-jenis miskonsepsi. Sehingga kini sememangnya tiada satu kajian lepas mengenai ujian diagnostik miskonsepsi nombor integer dengan analisis model Rasch dijalankan. Kaedah klasik dalam analisis data dan kesahan kandungan sahaja yang diutamakan dalam kajian-kajian lepas turut menjadi satu isu yang dibincangkan sejak akhir-akhir ini, kerana mempunyai kelemahan dari segi ciri-ciri psikometrik, iaitu kesahan kandungan dan unit peratusan menyebabkan kajian tersebut menghadapi masalah bergantungkumpulan (respondent-depend) dan bergantung-item (item-depend). Menurut Bond dan Fox (2015), kesahan kandungan tidak mencukupi untuk dijadikan bukti dalam penentuan kesahan konstruk ujian dan interprestasi ujian, kesahan konstruk yang diutamakan dalam model Rasch dikatakan lebih sesuai berbanding kesahan kandungan sahaja digunakan dalam penentuan kesahan instrumen. Dalam kajian ini, penglibatan model pseudo-konsepsi dan analisis miskonsepsi murid berdasarkan keluk OPC model Rasch dalam kajian ini membantu guru lebih mudah memahami miskonsepsi yang dihadapi oleh murid. Analisis model Rasch dalam miskonsepsi murid dengan keluk OPC lebih mudah para guru mengenal pasti jenis miskonsepsi murid berdasarkan aras kebolehan murid, justeru aktiviti atau penerangan yang lebih sesuai dan latihan pengukuhan boleh dilaksanakan oleh guru. 
Jadual 2. Analisis miskonsepsi item dalam instrumen UDOPNIN

\begin{tabular}{|c|c|c|c|c|c|}
\hline \multirow[b]{2}{*}{ Operasi penolakan } & \multirow[b]{2}{*}{$a-b$} & \multirow[b]{2}{*}{$\begin{array}{c}\text { Nombor } \\
\text { item }\end{array}$} & \multicolumn{3}{|c|}{ Jenis miskonsepsi } \\
\hline & & & $\begin{array}{l}\text { Aritmetik } \\
\text { (pseudo- } \\
\text { konsepsi } \\
\text { asimilasi) }\end{array}$ & $\begin{array}{c}\text { Simbol } \\
\text { (pseudo- } \\
\text { konsepsi } \\
\text { akomodasi) }\end{array}$ & $\begin{array}{c}\text { Aritmetik } \\
\& \text { simbol } \\
\text { (pseudo- } \\
\text { konsepsi } \\
\text { ekuilibrium) }\end{array}$ \\
\hline \multirow{10}{*}{$\begin{array}{l}\text { Integer positif } \\
\text { dengan integer } \\
\text { positif }\end{array}$} & $|a|>|b|$ & 6 & $\bullet$ & & \\
\hline & & 14 & $\bullet$ & $\bullet$ & \\
\hline & & 22 & & $\bullet$ & \\
\hline & & 32 & $\bullet$ & & \\
\hline & & 38 & $\bullet$ & & \\
\hline & $|\mathrm{a}|<|\mathrm{b}|$ & 4 & $\bullet$ & $\bullet$ & \\
\hline & & 25 & $\bullet$ & $\bullet$ & \\
\hline & & 26 & $\bullet$ & $\bullet$ & \\
\hline & & 34 & $\bullet$ & $\bullet$ & \\
\hline & & 36 & & $\bullet$ & \\
\hline \multirow{10}{*}{$\begin{array}{l}\text { Integer negatif } \\
\text { dengan integer } \\
\text { positif }\end{array}$} & $|\mathrm{a}|>|\mathrm{b}|$ & 1 & $\bullet$ & $\bullet$ & \\
\hline & & 13 & $\bullet$ & $\bullet$ & \\
\hline & & 16 & $\bullet$ & $\bullet$ & \\
\hline & & 24 & • & $\bullet$ & \\
\hline & & 37 & $\bullet$ & $\bullet$ & \\
\hline & $|\mathrm{a}|<|\mathrm{b}|$ & 3 & $\bullet$ & $\bullet$ & \\
\hline & & 9 & - & $\bullet$ & $\bullet$ \\
\hline & & 28 & $\bullet$ & $\bullet$ & $\bullet$ \\
\hline & & 30 & • & $\bullet$ & $\bullet$ \\
\hline & & 40 & $\bullet$ & $\bullet$ & $\bullet$ \\
\hline
\end{tabular}


Jadual 2. (sambungan)

\begin{tabular}{|c|c|c|c|c|c|}
\hline \multirow[b]{2}{*}{ Operasi penolakan } & \multirow[b]{2}{*}{$a-b$} & \multirow[b]{2}{*}{$\begin{array}{c}\text { Nombor } \\
\text { item }\end{array}$} & \multicolumn{3}{|c|}{ Jenis miskonsepsi } \\
\hline & & & $\begin{array}{c}\text { Aritmetik } \\
\text { (pseudo- } \\
\text { konsepsi } \\
\text { asimilasi) }\end{array}$ & $\begin{array}{l}\text { Simbol } \\
\text { (pseudo- } \\
\text { konsepsi } \\
\text { akomodasi) }\end{array}$ & $\begin{array}{c}\text { Aritmetik } \\
\& \text { simbol } \\
\text { (pseudo- } \\
\text { konsepsi } \\
\text { ekuilibrium) }\end{array}$ \\
\hline \multirow{10}{*}{$\begin{array}{l}\text { Integer positif } \\
\text { dengan integer } \\
\text { negatif }\end{array}$} & \multirow[t]{5}{*}{$|\mathrm{a}|>|\mathrm{b}|$} & 2 & $\bullet$ & $\bullet$ & \\
\hline & & 17 & $\bullet$ & $\bullet$ & $\bullet$ \\
\hline & & 21 & $\bullet$ & $\bullet$ & $\bullet$ \\
\hline & & 23 & $\bullet$ & $\bullet$ & $\bullet$ \\
\hline & & 39 & $\bullet$ & $\bullet$ & $\bullet$ \\
\hline & \multirow[t]{5}{*}{$|\mathrm{a}|<|\mathrm{b}|$} & 8 & & $\bullet$ & $\bullet$ \\
\hline & & 10 & & $\bullet$ & $\bullet$ \\
\hline & & 15 & & $\bullet$ & $\bullet$ \\
\hline & & 19 & & $\bullet$ & $\bullet$ \\
\hline & & 33 & $\bullet$ & $\bullet$ & $\bullet$ \\
\hline \multirow{10}{*}{$\begin{array}{l}\text { Integer negatif } \\
\text { dengan integer } \\
\text { negatif }\end{array}$} & \multirow[t]{5}{*}{$|\mathrm{a}|>|\mathrm{b}|$} & 5 & $\bullet$ & $\bullet$ & $\bullet$ \\
\hline & & 7 & $\bullet$ & $\bullet$ & $\bullet$ \\
\hline & & 12 & $\bullet$ & $\bullet$ & $\bullet$ \\
\hline & & 18 & $\bullet$ & $\bullet$ & $\bullet$ \\
\hline & & 20 & $\bullet$ & $\bullet$ & $\bullet$ \\
\hline & \multirow[t]{5}{*}{$|\mathrm{a}|<|\mathrm{b}|$} & 11 & $\bullet$ & $\bullet$ & $\bullet$ \\
\hline & & 27 & $\bullet$ & $\bullet$ & $\bullet$ \\
\hline & & 29 & $\bullet$ & $\bullet$ & $\bullet$ \\
\hline & & 31 & $\bullet$ & $\bullet$ & $\bullet$ \\
\hline & & 35 & $\bullet$ & $\bullet$ & $\bullet$ \\
\hline
\end{tabular}

\section{KESIMPULAN}

Instrumen UDOPNIN diharapkan dapat digunakan oleh para guru matematik tingkatan satu untuk mengesan jenis miskonsepsi murid yang menghadapi masalah dalam operasi penolakan nombor integer. Instrumen UDOPNIN yang mendapat kesahan yang baik dan kebolehpercayaan yang tinggi sememangnya dapat mengesan miskonsepsi yang dihadapi oleh murid dengan berkesan. Dalam instrumen UDOPNIN, setiap kategori operasi penolakan mempunyai lima 
item untuk mengesan jenis-jenis miskonsepsi yang mungkin berlaku terhadap seseorang murid. Contohnya, dalam Operasi Penolakan Integer Positif dengan Integer Positif, kategori $\mathrm{a}-\mathrm{b}=,(|\mathrm{a}|>|\mathrm{b}|)$ terdapat item nombor $1,9,17,25$, dan 33 untuk mengesan miskonsepsi murid. Murid yang melakukan jenis miskonsepsi yang sama sebanyak tiga item atau lebih, dikatakan menghadapi miskonsepsi tersebut. Oleh itu, para guru digalakkan menggunakan instrumen UDOPNIN ini untuk membantu murid dalam mengenal pasti miskonsepsi mereka, sterusnya menjalankan aktiviti pengukuhan.

Dari aspek teoritikal, kajian ini telah melengkapkan dan menyumbangkan secara langsung kepada perkembangan literatur teori kognitif Piaget, literatur model pseudo-konsepsi dan literatur model Rasch. Pemikiran model pseudo adalah satu konsep yang dikemukakan oleh Vinner (1997) untuk menggambarkan situasi murid yang gagal menguasai konsep sebenar yang disampaikan berdasarkan perkembangan teori kognitif Piaget. Penggunaan model pseudo-konsepsi dalam kajian ini bukan sahaja telah mengembangkan pemikiran model pseudo yang dikemukakan oleh Vinner, malahan telah melanjutkan teori kognitif Piaget dalam aspek miskonsepsi. Penggunaan model Rasch dalam kajian ini untuk analisis pengganggu (distractor analysis) dengan keluk OPC turut meningkatkan literatur model Rasch di Malaysia khasnya dari aspek analisis pengganggu. Hal ini kerana analisis pengganggu dengan keluk OPC dalam model Rasch merupakan sub-bidang baru bagi bidang psikometrik di Malaysia. Laporan kajian ini juga diharapkan dapat menjadi sumber rujukan sorotan literatur kepada pengkaji akan datang dalam aspek teori kognitif Piaget, model pseudo-konsepsi dan model Rasch.

Kajian yang dijalankan amat terhad, terbatas, dan hanya menumpu kepada sampel di negeri Pulau Pinang sahaja. Pengkaji sukar membuat kesimpulan terhadap topik nombor integer kerana hanya operasi penolakan sahaja yang ditumpukan dalam kajian ini. Kajian terhadap operasi tambah, darab dan bahagi perlu dilakukan pada masa akan datang untuk melengkapkan topik nombor integer ini. Ini kerana murid tingkatan satu bukan sahaja menghadapi miskonsepsi dalam operasi penolakan nombor integer, malahan miskonsepsi juga berlaku semasa murid menyelesaikan soalan operasi penambahan, darab atau bahagi nombor integer.

Sampel kajian juga harus diperluaskan ke negeri-negeri lain atau di seluruh Malaysia pada masa akan datang supaya hasil dapatan kajian dapat dibandingkan dengan dapatan kajian ini. Perbandingan boleh fokus kepada jenis miskonsepsi yang dilakukan oleh murid berdasarkan kebolehan murid dalam keluk OPC. Cadangan lain adalah pembangunan ujian diagnostik atas talian untuk memudahkan pengguna dalam proses mengenal pasti jenis miskonsepsi. Ujian diagnostik atas talian juga dapat memudahkan proses pengumpulan data, menjimatkan kos cetakan 
instrumen, menjimatkan masa menyemak instrumen, dan aktiviti pengukuhan selepas ujian diagnostik atas talian dijalankan dapat disediakan.

\section{RUJUKAN}

Ahmad Badli Sah. (1999). Sejauhmanakah kefahaman konsep nombor negatif dengan melihat kepada kemahiran asas pelajar-pelajar tingkatan dua. Unpublished undegraduate thesis, Universiti Teknologi Malaysia.

Alquraan, M., Alshraideh, M., \& Bsharah, M. (2010). Psychometric properties and Differential Item Functioning (DIF) analyses of Jordanian version of self-assessed wisdom scale (SAWS-Jo). International Journal of Applied Educational Studies, 9(1), 52-66.

Bahagian Pembangunan Kurikulum. (2010). Sukatan pelajaran MATEMATIK Kurikulum Bersepadu Sekolah Menengah. Kuala Lumpur: Kementerian Pelajaran Malaysia.

Bhasah Haji Abu Bakar. (2007). Pengujian, pengukuran dan penilaian pendidikan. Kuala Lumpur: Pustaka Salam Sdn. Bhd.

Bofferding, L. (2010). Addition and subtraction with negatives: Acknowledging the multiple meanings of the minus sign. Retrieved 2 March 2018, from http://social. education.purdue.edu/bofferding/wp-content/uploads/2011/08/2010-BofferdingAddition-and-subtraction.pdf

Bofferding, L. (2014). Negative integer understanding: Characterizing first graders' mental models. Journal for Research in Mathematics Education, 45(2), 194-245. https:// doi.org/10.5951/jresematheduc.45.2.0194

Bolyard, J., \& Moyer-Packenham, P. S. (2012). Making sense of integer arithmetic: The effect of using virtual manipulatives on students' representational fluency. Journal of Computers in Mathematics and Science Teaching, 31(2), 93-113.

Bond, T. G. \& Fox, C. M. (2015). Applying the Rasch model. New York: Routledge. https://doi.org/10.4324/9781315814698

Cohen, R. J., Swerdlik, M. E., \& Sturman E. D. (2013). Psychological testing and assessment: An introduction to tests and measurement (8th ed.). New York: McGraw Hill.

Fleiss, J. (1981). Statistical methods for rates and proportions (2nd ed.). New York: John Wiley.

Hambleton, R. K. \& Rogers, H. J. (1989). Detecting potentially biased test items: Comparison of IRT area and Mantel-Haenszel methods. Applied Measurement in Education, 2(4), 313. https://doi.org/10.1207/s15324818ame0204_4

Herrmann, C. F., \& DeBoer, G. E. (2011). Using distractor-driven standards-based multiple-choice assessments and rasch modeling to investigate hierarchies of chemistry misconceptions and detect structural problems with individual items. Chemistry Education Research and Practice, 12, 184-192. https://doi. org/10.1039/C1RP90023D 
Herrmann, C. F., \& DeBoer, G. E. (2016). Using Rasch modeling and option probability curves to diagnose students' misconceptions. 2016 AERA Annual Meeting, Washington, DC.

Kamarudin Husin, \& Siti Hajar Abdul Aziz. (2004). Pedagogi asas pendidikan. Kuala Lumpur: Kayazano Enterprise.

Lembaga Peperiksaan Malaysia. (1993). Laporan Prestasi PMR 1993. Kuala Lumpur: Kementerian Pendidikan Malaysia.

Lembaga Peperiksaan Malaysia. (2002). Laporan Prestasi PMR 2002. Kuala Lumpur: Kementerian Pelajaran Malaysia.

Lembaga Peperiksaan Malaysia (2003a). Laporan Prestasi PMR 2003. Kuala Lumpur: Kementerian Pelajaran Malaysia.

Lembaga Peperiksaan Malaysia. (2003b). Laporan Prestasi SPM 2003. Kuala Lumpur: Kementerian Pelajaran Malaysia.

Lembaga Peperiksaan Malaysia. (2007). Kupasan Mutu Jawapan SPM 2007. Kuala Lumpur: Kementerian Pelajaran Malaysia.

Lembaga Peperiksaan Malaysia. (2010). Kupasan Mutu Jawapan SPM 2010. Kuala Lumpur: Kementerian Pelajaran Malaysia.

Lembaga Peperiksaan Malaysia. (2012). Kupasan Mutu Jawapan SPM 2012. Kuala Lumpur: Kementerian Pelajaran Malaysia.

Lembaga Peperiksaan Malaysia. (2014). Kupasan Mutu Jawapan SPM 2014. Kuala Lumpur: Kementerian Pendidikan Malaysia.

Lily, C., \& Su-Jen, L. (2015). A Rasch model distractor analysis on ordered multiple-choice items of a fractional test. Journal of Education \& Psychology, 38(2), 87-119.

Linacre, J. M. (2003). Winsteps Computer Program Version 3.57.2. Retrieved 24 April 2016, from http://www.winsteps.com

Lynn, M. R. (1986). Determination and quantification of content validity. Nursing Research, 35, 382-385. https://doi.org/10.1097/00006199-198611000-00017

Marlina Ali, \& Nurhidayah Uzir. (2011). Tahap kefahaman pelajar tingkatan dua bagi topik nombor negatif. Retrieved 25 February 2018 from http://eprints.utm.my/11042/ 1/ Tahap_Kefahaman_Pelajar_Tingkatan_Dua_Bagi_Topik_Nombor_Negatif.pdf

Mohammad Sopian Zakaria (2011). Masalah pembelajaran matematik di kalangan pelajar tingkatan satu dalam tajuk integer. Unpublished undergraduate thesis, Universiti Teknologi Malaysia.

Nitko, A. J. (2014). Educational assessment of students (6th ed.). USA: Pearson.

Normunirah Abd. Mubing. (2006). Kesalahan lazim pelajar tingkatan dua mengenai nombor negatif di Sekolah Menengah Kebangsaan Pengkalan Chepa (1), Kota Bharu Kelantan. Unpublished undergraduate thesis, Universiti Teknologi Malaysia.

Nyiayu F. F., Didi, S., \& Turmudi. (2017). Some difficulties in understanding negative numbers faced by students: A qualitative study applied at secondary schools in Indonesia. International Education Studies, 10(1), 24-38. https://doi.org/10.5539/ ies.v10n1p24

Periasamy, E. (2014). Meramal proses kesilapan pemikiran untuk operasi penolakan nombor negatif melibatkan integer positif dengan negatif. Jurnal Personalia Pelajar, 17, 41-48. 
Periasamy, E., \& Halimah Badioze Zaman. (2011). Predict incorrect thinking process: Negative numbers subtraction operation second category. Paper presented at the Proceeding of the International Conference on Advanced Science, Engineering and Information Technology 2011, Fakulti Teknologi Sains Maklumat, Universiti Kebangsaan Malaysia, Bangi.

Periasamy, E., \& Halimah Badioze Zaman. (2012). Remedial process for negative numbers subtraction operation: a computerized diagnostic assessment. International Journal on Advanced Science Engineeing Information Technology, 2(2), 62-66. https://doi.org/10.18517/ijaseit.2.6.247

Sadler, J. T. (2012). The positives about negatives: A study of errors and misconceptions with integer operartions in adult education. Unpublished Masters thesis, State University of New York.

Subanji \& Toto Nusantara. (2016). Thinking process of pseudo construction in mathematics concepts. International Education Studies, 9(2), 17-31. https://doi.org/10.5539/ ies.v9n2p17

Suparno, P. (2005). Miskonsepsi dan perubahan konsep dalam pendidikan fisika. Jakarta: Grasindo.

Titikusumawati, E. (2013). Analisis miskonsepsi terhadap operasi penjumlahan dan pengurangan bilangan bulat menggunakan garis bilangan pada mahasiswa STAIN Salatiga. Retrieved 25 February 2018 from, http://download.portalgaruda. org $/$ article.php article $=273525 \&$ val $=7135 \&$ title $=$ Analisis $\% 20$ Miskonsepsi $\% 20$ terhadap $\% 20$ Operasi $\% 20$ Penjumlahan $\% 20$ dan $\% 20$ Pengurangan $\% 20 \% 20$ Bilangan\%20Bulat $\% 20$ menggunakan $\% 20$ Garis $\% 20$ Bilangan $\% 20 \% 20$ pada $\% 20$ Mahasiswa\%20STAIN\%20Salatiga

Vinner, S. (1997). The pseudo-conceptual and the pseudo-analytical thought processes in mathematics learning. Educational Studies in Mathematics, 34(2), 97-129. https://doi.org/10.1023/A:1002998529016

Wind, S.A. \& Gale, J.D. (2015). Diagnostic opportunities using Rasch measurement in the context of a misconceptions-based physical

Wong, S. M. (2012). Kajian tindakan ops operasi integer. Retrieved 13 June 2018 from, http://teacherwongsm.blogspot.com/2012/06/kajian-tindakan-ops-operasiinteger.html 